Relations industrielles

Industrial Relations

\title{
The Politics of Pure Science, by Daniel S. Greenberg, The New American Library, New-York, 1967, 303 pages.
}

\section{L.-René Parenteau}

Volume 23, numéro 2, 1968

URI : https://id.erudit.org/iderudit/027906ar

DOI : https://doi.org/10.7202/027906ar

Aller au sommaire du numéro

Éditeur(s)

Département des relations industrielles de l'Université Laval

ISSN

0034-379X (imprimé)

1703-8138 (numérique)

Découvrir la revue

Citer ce compte rendu

Parenteau, L.-R. (1968). Compte rendu de [The Politics of Pure Science, by Daniel S. Greenberg, The New American Library, New-York, 1967, 303 pages.]

Relations industrielles / Industrial Relations, 23(2), 369-370.

https://doi.org/10.7202/027906ar

Tous droits réservés (C) Département des relations industrielles de l'Université Laval, 1968
Ce document est protégé par la loi sur le droit d'auteur. L’utilisation des services d'Érudit (y compris la reproduction) est assujettie à sa politique d'utilisation que vous pouvez consulter en ligne.

https://apropos.erudit.org/fr/usagers/politique-dutilisation/ 
i) fout mointenir un équilibre raisonnable entre les responsabilités administratives et les activités scientifiques si on ne veut pas noyer l'esprit créateur des chercheurs.

L'âge est un poramètre important dans toute décision que l'on doit prendre, en ce qui concerne l'affectation de la main-d'oeuvre sovante, car il est un déterminant important de l'efficacité: Non pas tant que les capocités intellectuelles varient ou diminuent avec le temps, mais parce que les motivations et les intérêts changent, de sorte qu'il est important d'étudier la possibilié de certains changements même fondamentoux dans les plans de carrière vers l'âge de quarante ans. Ainsi il n'est pas inutile pour certains chercheurs qu'ils aient la possibilité d'évoluer de la recherche fondamentale à la recherche appliquée.

Les auteurs étudient également la forme d'organisation qui convient le mieux aux scientifiques. II ressort de leurs études qu'une organisation flexible et même lâche va de poir crec un rendement élevé si les chercheurs sont d'abord fortement motivés pour leurs travaux. De plus, les auteurs établissent une relation entre l'autonomie dans le travail et la nature de l'organisation. Leurs conclusions sont ò l'effet « that a relatively high level of individual autonomy wos effective mainly in the middle range of situations - those which were neither very highly co-ordinated nor lose. In the latter where members already enjoyed considerable freedom, the most autonomous scientists were below average in performance $\$$.

\section{Gérald MARION}

La population octive et so structure, Statistiques internationales retrospectives, volume I sous lo direction de P. Bairoch, Université Libre de Bruxelles, Editions de I'Institut de Sociologie, 1968, 236 pp.

Le premier volume de la collection - Statistiques Internationales Rétrospectives * inaugure une série de publications destinée à fournir pour tous les territoires et pour toutes les périodes pour lesquelles les données sont accessibles, des séries historiques oussi homogènes que possible sur les divers aspects de la structure ou de l'activité économique et sociale.

Cette compilation stotistique représente une source d'information d'un intérêt capital pour les chercheurs relevant de diverses disciplines qui sous un angle ou un autre sont vouées à l'étude des sociétés industrielles et de leur développement.
Lo bibliographie annexée à cet ourrage en occroit encore l'intérêt et contient notomment de précieuses indicotions pour entreprendre de fructueuses études comparatives.

\section{Bernard SOLASSE}

The Politics of Pure Science, by Doniel S. Greenberg, The New American Library, New-York, 1967, 303 pages.

The Politics of Pure Science is first of all a complete history which reports the numerous experiences, adventures and conflicts that led to the organization of research in America. Reading this interesting book, we are brought to know everything about committees, conferences, associations and centres especially created to develop pure science and to give the American technology its first place on the screen world. Daniel Greenberg clears out the exact participation of each group of the society in that effort. He tells us the predominant role and support of the federal government, the participation of private groups - enterprises, universities, committees and associations. Then he remembers us the great names associated with the great discoveries and creations of this century, associated with the foundation of the main associations for the advancement of science in America. We could say that he is a tremendous searcher himself who cannot suffer vagueness.

But this book is more than an history and we would lack respect toward Mr. Greenberg if we did not mention the interest he showed toward the great problems that face science and scientists. He clearly indicated in that book, first the xenophobio of scientists, second the will of public and private interests to dominate science and moke it serve them. He did it when he reminded us the creation of the atomic bomb, the numerous military uses of science during both world wars. For the future he asks how the government, which becomes the first supporter of reseorch in pure science, will be brought to make science serve the interests of man.

His last chapter, entitled "The New Politics of Science $\$$, gives us some hope when he explains how science is being now brought under the control of democracy and how by the decentralization of research, science will be placed under the control of science, under the control of the nation. But the citizens will not be able to make o choice between infinite needs unless they get good education and new values that will 
make them mosters and not servonts of science.

It is definitely a book to read even if we ore bent to poss over a few chapters much too concerned by historical and technical details.

\section{L.-René PARENTEAU}

Rotation des stocks et marge bénéficiaire ò l'américaine, par John P. D'Anna, Entreprise Moderne d'Edition, Paris, 1968, 90 pp.

Le livre de John P. D'Anno de la General Ford publié en 1966 sous le titre américain - Inventory and Profit» par The American Manogement Association Inc. est d'un accès focile, sans tomber dans la simplification abusive qu'entraîne trop souvent le souci de vulgariser. II constitue par conséquent une excellente introduction à cet aspect particulier du marketing dont il traite. La compréhension est de plus largement favorisée par l'insertion en annexe d'une série de questions qui s'adressent au lecteur.

Les idées développées dans cet ouvrage sont suffisamment connues en Amérique du Nord pour que nous puissions foire l'économie d'un long commentaire.

L'édition française porte en sous titre - à l'oméricaine ». Y aurait-il dans ce domaine des différences fondamentales entre les Etats-Unis et l'Europe et plus particulièrement la France? Les succès remportés par les firmes américaines nouvellement implantées dans les six pays de la Communouté économique européenne tendent à démontrer que les principes du marketing américain sont au prix de quelques ajustements mineurs parfaitement compatibles avec les conditions particulières existant outre Atlantique.

\section{Bernard SOLASSE}

Great Myths of Economics, by Don Poarlberg, The New American Library Inc., New York, 1968, $206 \mathrm{pp}$.

$\mathrm{Ce}$ livre essaie de dissiper les grands mythes économiques qui ont été acceptés comme des évangiles par les profanes. Pour être bien compris de tous, l'auteur emploie un langage simple et concis

Avec objectivité le professeur Poarlberg tente, dons une première partie, de détruire les fausses croyances d'un public mal informé au sujet des politiques monétaires, du contrôle gouvernemental, des biens de con- sommation privés et socioux, de l'exploitation, etc. Puis, dans une seconde partie, i expose les principaux concepts de la politique économique moderne tels: le marché de concurrence, le marché de monopole, la consommation, la production, les salaires, la monnaie, le crédit et les prix ainsi que le développement économique. Finalement, il termine avec un appendice dans lequel if mentionne les principoux autres travaux qui ont écrits sur les problèmes économiques récents.

Tout au long du volume, I'auteur situe lo théorie et lo pratique économiques ò portir des dogmes des économistes classiques et marxistes jusqu'ò la révolution keynesienne.

Grâce ò so connaissance du sujet et son exceptionnel talent d'écrivain lucide, le professeur Poarlberg permet au lecteur de comprendre le fonctionnement pratique du monde économique compliqué dans lequel nous vivons.

L'outeur indique clairement au déport so ferme conviction dans la supériorité de l'économie de marché telle que nous la connaissons en Occident. Par contre, durant tout le volume, il indique les différentes alternatives face à des problèmes économiques bien concrets.

En critiquant les solutions des premiers économistes de la civilisation industrielle, l'auteur ne se fera sûrement pas d'amis parmi les gens d'extrême droite ni d'extrême gauche. Ainsi, s'il reconnait les désavantages d'une économie libérale laissée pleinement à elle seule, il condamne aussi bien les contrôles rigides de l'Etat.

Par conséquent, le livre Great Myths of Economics illumine clairement les principaux principes qui guident le comportement de I'homme selon qu'il sait s'en servir adéquatement ou qu'il en abuse.

\section{Jean BOIVIN}

Lo stratégie des négociations collectives, par Denis Carrier, Les Presses Universitaires de France: [Travaux et recherches de la Faculté de Droit et des Sciences Economiques de Paris, série «Sciences Economiques ע, no 5 , préfacé por Henri Bartoli, 160 pages, 1967 - 4]

L'auteur se propose de rechercher une méthode et une opproche pour systématiser I'analyse des rapports collectifs du travail. 